\title{
Study on the Pore-formers for Porous Anode Substrates of Solid Oxide Fuel Cell
}

\author{
Yang Jianjun ${ }^{1}, \quad$ Ma Wenhui ${ }^{1}, \quad$ Yu Jie ${ }^{1}, \quad$ Chen Xiuhua ${ }^{2}, \quad$ Sun Hongyan ${ }^{1}, \quad$ Xie Yubing ${ }^{1}$ \\ ${ }^{1}$ National Engineering Laboratory for Vacuum Metallurgy, Kunming University of Science and Technology, Kunming 650093, China; ${ }^{2}$ Yunnan \\ University, Kunming 650091, China
}

\begin{abstract}
La}_{0.7} \mathrm{Sr}_{0.3} \mathrm{Cr}_{0.5} \mathrm{Mn}_{0.5} \mathrm{O}_{3-\delta}$ (LSCM) ultrafine powder was synthesized using glycine-nitrate process. Three kinds of pore-formers(activated carbon, starch and graphite) with different ratios were mixed with the LSCM powders to prepare porous anode substrates. The porosity of the anode substrate was measured by the Archimedes method, and the maximum porosity was $45 \%$. The morphology and the structure of the anode substrates were characterized by SEM, XRD and EDS. XRD analysis displays that the LSCM substrates are main perovskite phases after sintering. SEM analyses show that the pore distribution of the anode substrate prepared by adding $20 \mathrm{wt} \%$ activated carbon is more uniform than those of the substrates prepared by starch and graphite, and no cracks appear. The catalytic experiments results demonstrate that the porous anode substrate prepared by adding $20 \mathrm{wt} \%$ activated carbon as the pore-former has the best methane catalytic performance at high temperature, and the corresponding conversion efficiency is $71.88 \%$.
\end{abstract}

Key words: glycine-nitrate process; anode substrate; porosity; methane conversion efficiency

Solid oxide fuel cells (SOFCs) have recently attracted great attention for their ability to convert the chemical energy of (hydrogen, natural gas, et al) directly into electrical energy. This conversion is characterized by high efficiency and low greenhouse gas emissions ${ }^{[1-4]}$. Like batteries, solid oxide fuel cells consist of an electrolyte sandwiched between an anode and a cathode.

The conventional SOFC supported by the electrolyte substrate has great internal ohmic resistance due to the high resistance of the electrolyte. Many research works were performed to reduce the electrolyte resistance. High temperatures of $800 \sim 1000^{\circ} \mathrm{C}$ were adopted to decrease the resistance ${ }^{[5]}$, but it easily caused the cells instability and the electrical performance deterioration ${ }^{[6]}$. Developing a low-intermediate temperature SOFC is not only helpful to enhance the cell stability, but it also can reduce cell operating cost. However, the resistance of the electrolyte substrate becomes too large at low temperature. There are two ways to decrease the cell internal resistance at low-intermediate temperatures. One is to seek the high conductivity substitutes, such as doping ceria or lanthanum gallate ${ }^{[7]}$. The other way is to apply anode-supported cells or cathode-supported cells, and the electrolyte layer thickness can be reduced from $100 \mu \mathrm{m}$ to $5 \sim 20 \mu \mathrm{m}^{[8]}$, therefore the cell resistance is greatly decreased.

Nowdays, the main electrolyte is yttria-stabilized zirconia $\left(\mathrm{YSZ}^{[2]}\right.$. And the anode materials commonly adopt Ni/YSZ cermets, which provide excellent catalytic properties for fuel oxidation and current collection, but they also exhibit many disadvantages, such as low tolerance to sulphur ${ }^{[9]}$, high carbon deposition ${ }^{[10]}$ Upon using hydrocarbon fuels and structure instability in redox cycling. Tao et al. firstly reported the electrode materials of $\mathrm{La}_{0.75} \mathrm{Sr}_{0.25} \mathrm{Cr}_{0.5} \mathrm{Mn}_{0.5} \mathrm{O}_{3-\delta}$, and they found $\mathrm{La}_{0.75} \mathrm{Sr}_{0.25} \mathrm{Cr}_{0.5} \mathrm{Mn}_{0.5} \mathrm{O}_{3-\delta}$ polarization resistance approached $0.2 \Omega \cdot \mathrm{cm}^{2}$ at $900{ }^{\circ} \mathrm{C}^{[11]}$. A good performance has been achieved for methane oxidation without excess steam. The anode is stable in both fuel and air conditions, especially shows stable electrode performance in methane. Chen et al. reported the anode materials $\mathrm{La}_{0.7} \mathrm{Sr}_{0.3} \mathrm{Cr}_{0.5} \mathrm{Mn}_{0.5} \mathrm{O}_{3-\delta}$ (LSCM)

Received date: March 10, 2013

Foundation item: Natural Science Foundation of Yunnan Province (2009ZC027M); Innovation Fund of Science and Technology for Students (2012YA027)

Corresponding author: Ma Wenhui, Ph. D., Professor, National Engineering Laboratory for Vacuum Metallurgy, Faculty of Metallurgical and Energy Engineering, Kunming University of Science and Technology, Kunming 650093, P. R. China, Tel: 0086-871-5161583, E-mail: mwhsilicon@163.com 
and tested the LSCM conductivities at different atmospheres ${ }^{[12]}$. However, the anode substrates demanded for porous structure due to the fuel gas transferring to triple phase boundary $(\mathrm{TPB})^{[13]}$. In order to obtain an appropriate porosity for fuel gas, starch, graphite, polymethyl methacrylate, ammonium oxalate and ammonium carbonate were widely used as pore-formers to fabricate porous structure materials ${ }^{[13-19]}$, and the results showed that the pore-formers amounts affected the pore sizes and pore distributions, which seriously influenced the gas amount and the anode catalytic activity for fuel gas $^{[20,21]}$. Therefore, choosing a suitable pore-former and a pore-former amount to prepare porous anode substrates is essential for improving the fuel cells performance.

In this work, LSCM anode materials were synthesized using glycine-nitrate process (GNP). And different amounts of starch, activated carbon and graphite were selected as pore-formers mixing with LSCM anode materials to form pores. The porosity, catalytic property and microstructure of the anode substrates were also discussed.

\section{Experiment}

$\mathrm{La}_{0.7} \mathrm{Sr}_{0.3} \mathrm{Cr}_{0.5} \mathrm{Mn}_{0.5} \mathrm{O}_{3-\delta}$ powders were synthesized by using glycine-nitrate process ${ }^{[12,22-24]} \cdot \mathrm{La}\left(\mathrm{NO}_{3}\right)_{3} \cdot 6 \mathrm{H}_{2} \mathrm{O}, \mathrm{Sr}\left(\mathrm{NO}_{3}\right)_{2} \cdot 6 \mathrm{H}_{2} \mathrm{O}$, $\mathrm{Cr}\left(\mathrm{NO}_{3}\right)_{3} \cdot 6 \mathrm{H}_{2} \mathrm{O}$ and $\mathrm{Mn}\left(\mathrm{NO}_{3}\right)_{2}$ were dissolved in de-ionized water with a definite stoichiometric ratio. Then the molar amount of glycine, which acted as a complexing agent, was 1.5 times as much as that of nitrates in the solution. The solution was stirred and heated on a hot plate until the selfcombustion phenomenon appeared and formed loose pow$\operatorname{ders}^{[22-23]}$. Then the powders were calcined at $1350{ }^{\circ} \mathrm{C}$ for $2 \mathrm{~h}$.

Starch, activated carbon and graphite were obtained as pore-formers, mixed with LSCM anode powders in an agate mortar. Table 1 show the pore-formers amounts. The mixtures were pressed into pellets with $20 \mathrm{~mm}$ diameter and $1 \mathrm{~mm}$ thickness under $10 \mathrm{MPa}$ pressure. Then the pellets were sintered at $1350{ }^{\circ} \mathrm{C}$ for $4 \mathrm{~h}$ to fabricate anode substrates. The structure of LSCM substrate was characterized by X-ray diffraction with $\mathrm{Cu}$ $\mathrm{K} \alpha$ radiation. The selected $2 \theta$ was from $10^{\circ}$ to $90^{\circ}$ scanning at an increment of $0.02^{\circ}$. Energy dispersive spectroscopy (PHOENIX) was used to test the LSCM materials composition. The substrate porosity was determined by the Archimedes method. The

Table 1 Samples with different pore-formers (wt $\%)$

\begin{tabular}{ccc}
\hline No. & Pore-former & Amount \\
\hline A1 & Activated carbon & 10 \\
A2 & Activated carbon & 15 \\
A3 & Activated carbon & 20 \\
G4 & Graphite & 25 \\
G5 & Graphite & 30 \\
G6 & Graphite & 35 \\
S7 & Starch & 5 \\
S8 & Starch & 8 \\
S9 & Starch & 10 \\
\hline
\end{tabular}

cross-sectional and surface morphologies were observed by a scanning electron microscope (Philips XL30SEM).

There are many kinds of fuels for SOFC, such as $\mathrm{H}_{2}$, syngas, water gas and so on. If methane is directly adopted as fuel, the conventional process of converting natural gas can be removed, which would greatly reduce the power generation cost In the reaction process, the methane molecules and oxygen ions react at the TPB of the cells, the electrochemical reactions show as following:

Partial oxidation: $\mathrm{CH}_{4}+\mathrm{O}^{2-} \longrightarrow \mathrm{CO}+2 \mathrm{H}_{2}+2 \mathrm{e}$

Complete oxidation: $\mathrm{CH}_{4}+4 \mathrm{O}^{2-} \longrightarrow \mathrm{CO}_{2}+2 \mathrm{H}_{2} \mathrm{O}+8 \mathrm{e}$

Three kinds of anode substrates prepared by adding $8 \mathrm{wt} \%$ starch, $20 \mathrm{wt} \%$ activated carbon and $35 \mathrm{wt} \%$ graphite as pore-formers were employed to research the methane catalytic properties. Methane reacted with mixture gases consisting of nitrogen and oxygen at the temperature range of $550 \sim 800{ }^{\circ} \mathrm{C}$, and the molar ratio of three kinds of gas was $2: 4: 4$, the gas flow rate was $10 \mathrm{~mL} / \mathrm{min}$. Gas chromatography (Agilent Technologies 7890) was used to measure the amounts of methane and oxygen before and after the reactions. Comparing the change of the gases amounts, it is easy to estimate whether the anode substrates have methane catalytic performance and calculate the methane conversion efficiencies.

\section{Results and Discussion}

\subsection{XRD and EDS analysis of LSCM}

XRD pattern of the anode substrate is shown in Fig.1. The substrate is mainly comprised of LSCM materials with perovskite phase after being sintered at $1350{ }^{\circ} \mathrm{C}$ for $4 \mathrm{~h}$, which indicates that glycine nitrate process can obtain LSCM materials with perovskite phase. Referred the literatures ${ }^{[22,24]}$, the pore-formers don't affect the crystal structure of the LSCM materials during sintering.

EDS pattern of the LSCM anode materials is shown in Fig.2, the LSCM anode materials only contain $\mathrm{La}, \mathrm{Sr}, \mathrm{Cr}, \mathrm{Mn}$ and $\mathrm{O}$ five elements. The LSCM composites are given in Table 2. Comparing with the experimental design molar ratios of 0.7:0.3:0.5:0.5:3- $\delta$, the test molar ratio of $\mathrm{La}, \mathrm{Sr}, \mathrm{Mn}, \mathrm{Cr}$ and $\mathrm{O}$ elements is $0.7: 0.29: 0.53: 0.45: 2.18$. Only the Mn amount in the sample is slightly lower than that of the initial design. It

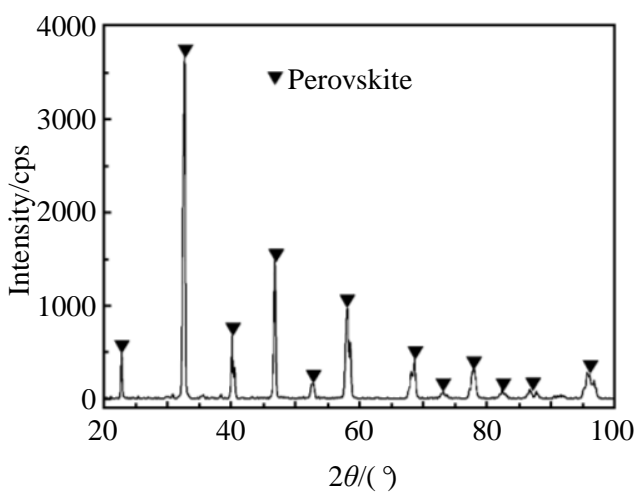

Fig.1 XRD pattern of LSCM anode substrate 


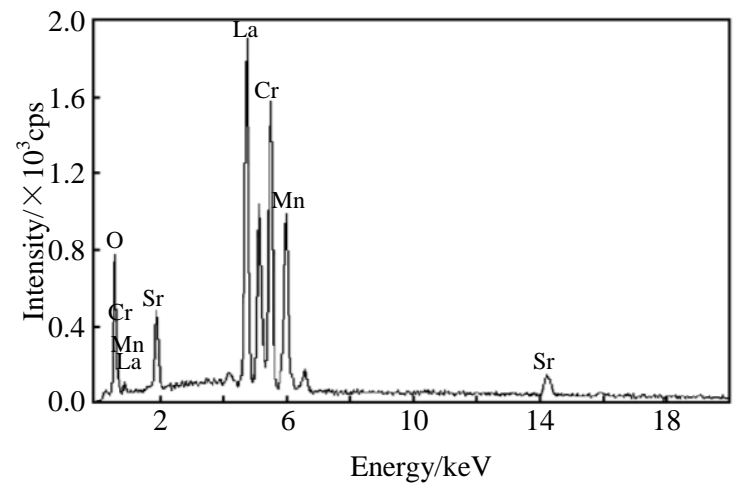

Fig.2 EDS spectra of LSCM anode materials

Table 2 Composites of the LSCM substrate prepared by GNP

\begin{tabular}{cccccc}
\hline Element & $\mathrm{La}$ & $\mathrm{Sr}$ & $\mathrm{Cr}$ & $\mathrm{Mn}$ & $\mathrm{O}$ \\
\hline $\mathrm{wt} \%$ & 46.45 & 12.04 & 13.06 & 11.82 & 16.62 \\
$\mathrm{at} \%$ & 16.91 & 6.95 & 12.71 & 10.88 & 52.55 \\
\hline
\end{tabular}

can be concluded that the anode materials prepared by GNP basically meet the materials design requirements.

\subsection{Porosity of anode substrate}

The anode substrate porosity is very important to gas transport. Fig.3a, $3 \mathrm{~b}$ and $3 \mathrm{c}$ show the porosities of LSCM anode substrates prepared by adding activated carbon, graphite and starch, respectively. Fig.3d indicates the comparison of the porosities of samples A3, G6 and S8. From Fig.3a, it can be seen that the porosity values increase with enlargement of activated carbon amount, and the porosities obtained in the experiments are higher than those of the samples in the literature $^{[20]}$. The porosities of samples G4, G5, G6 are 36.4\%, 35\% and $37.6 \%$ are shown in Fig.3b, which is in agreement with the report of Sahu where the open porosity of LSM was $37 \%$ ${ }^{[14]}$. The porosities of samples S7, S8, S9 are 33.3\%, 45\% and $28.5 \%$, repectively. Liu et al. added potato starch into the Ni-YSZ powders, the porosity of the substrate was $40 \%$ when the potato starch amount was $10 \%$, which was higher than that of the sample $\mathrm{S} 9$, but lower than that of sample $\mathrm{S} 8^{[15]}$. Starch decomposed at $294{ }^{\circ} \mathrm{C}^{[25]}$, the LSCM particles contacted each other seriously at elevated temperature. With increasing of starch amounts, the shrinkage of LSCM anode substrates will become great, and the porosity of the anode substrate is reduced $^{[26]}$. It can be concluded that $20 \mathrm{wt} \%$ activated carbon and $8 \mathrm{wt} \%$ starch have outstanding ability for fabricating porous structures, and the porosities are both higher than $44 \%$.

\subsection{Surface and cross-sectional morphologies of anode substrates}

LSCM substrate microstructures were observed by SEM. The surface and cross-sectional morphologies of the anode substrates are shown in Fig.4. Fig.4a display an uniform pores distribution, a regular pore shape and a moderate pore size. However, Fig.4b show a uneven pores distribution, an irregular pore shape and some cracks, this may be attributed to the
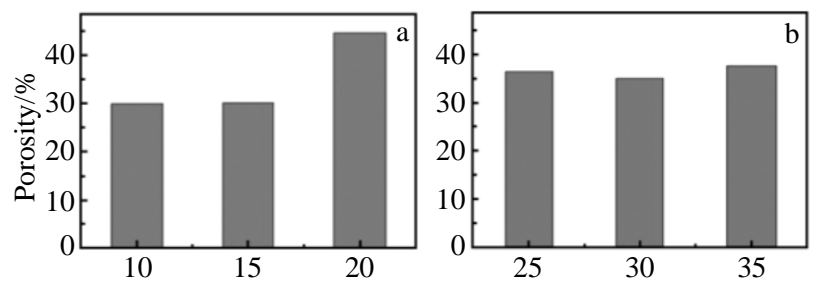

Content of Activated Carbon/wt $\%$ Content of Graphite/wt $\%$
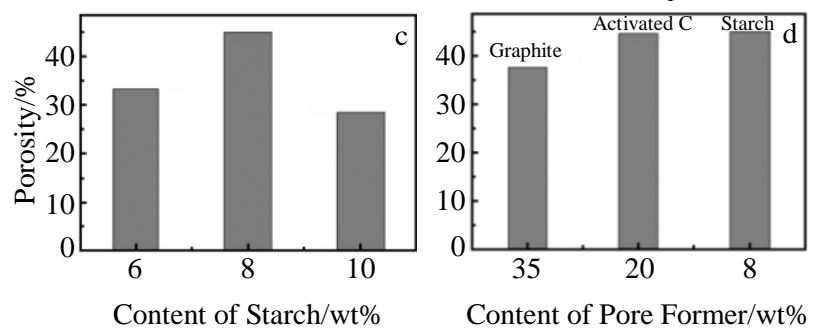

Fig.3 Porosities of different LSCM anode substrates prepared by adding activated carbon (a), graphite (b), starch (c), and the maximum values comparison of activated carbon, graphite, starch (d)

graphite agglomerate in large particles. The cracks are detrimental to electron conducting, resulting to enlarging the substrate resistance. Fig.4c exhibit some cracks and regular pores, but pore size vary greatly and some closed-pores appear. There are two reasons accounting for the closed-pores. Firstly, the decomposition temperature of starch is very low ${ }^{[25]}$, the LSCM particles easily aggregate to form the closed-pores when temperature elevates. Secondly, the starch amounts added into the samples are very little. In the mix process, the starch powder is surrounded by LSCM powder, and the LSCM particles contact closely to form coarse LSCM particles and closed-pores after sintering.

\subsection{Methane conversion efficiencies}

The methane conversion efficiencies of the samples A3, G6 and $\mathrm{S} 8$ are shown in Fig.5. It can be found that the methane conversion efficiencies increase from $550{ }^{\circ} \mathrm{C}$ to $700{ }^{\circ} \mathrm{C}$, but reduce from $700{ }^{\circ} \mathrm{C}$ to $800{ }^{\circ} \mathrm{C}$. Methane conversion efficiency peaks appear at $700{ }^{\circ} \mathrm{C}$, and the maximum of the efficiency is $71.88 \%$. With increasing of temperature, $\mathrm{CH}_{4}$ reacts with $\mathrm{O}_{2}$ to generate an intermediate produce $\mathrm{CH}_{4} \ddot{\mathrm{O}} \mathrm{O}_{2}$, which is bad for the conversion from $\mathrm{CH}_{4}$ to $\mathrm{H}_{2}$ and $\mathrm{CO}$. When the temperature is higher than $700{ }^{\circ} \mathrm{C}$, the methane conversion efficiency decreases ${ }^{[27]}$. Aschroft et al ${ }^{[28]}$ found that the methane catalysis activity reduced and the methane conversion efficiency decreased at high temperature. The change trends of curve $b$ and curve $\mathrm{c}$ are very uniform, the methane conversion efficiency of substrate prepared by adding graphite is similar that of adding starch. Sample A3 prepared by adding $20 \mathrm{wt} \%$ activated carbon has the lowest conversion efficiency below $700^{\circ} \mathrm{C}$, but has the highest conversion efficiency when temperature is higher than $700{ }^{\circ} \mathrm{C}$.

The samples G6 and S8 have some cracks shown in Fig.4, 

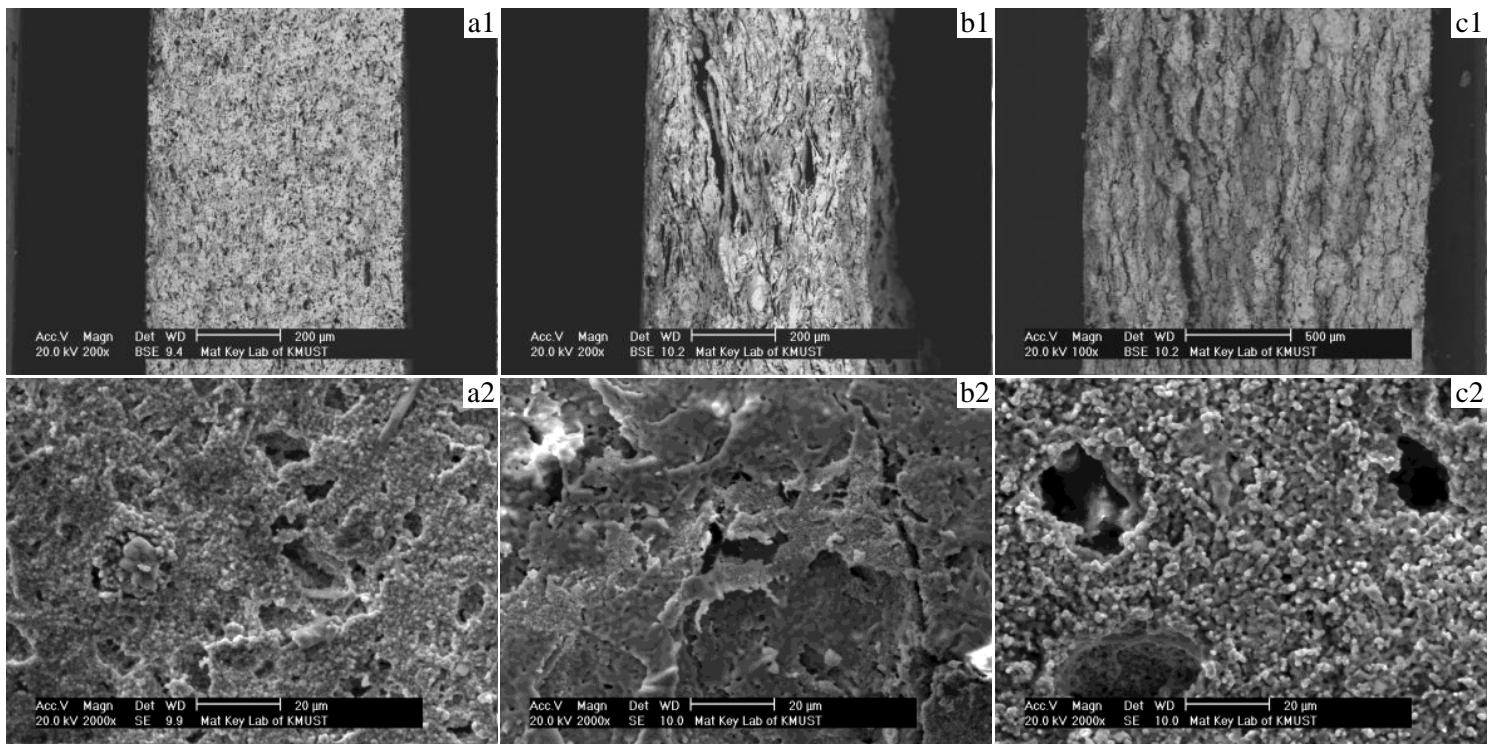

Fig.4 SEM images of LSCM anode substrates by adding $20 \mathrm{wt} \%$ activated carbon (a), $35 \mathrm{wt} \%$ graphite (b), and 8 wt $\%$ starch (c)

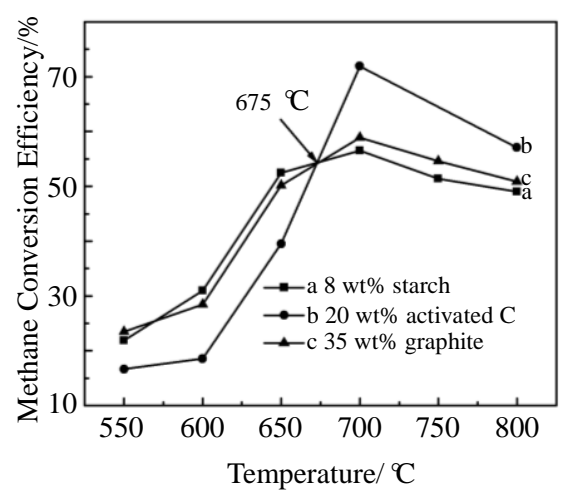

Fig.5 Methane conversion efficiencies of the anode substrates

which is attributed to a gas flow and catalytic reactions. That is the reason why the methane conversion efficiency of substrates by adding graphite or starch is higher than that of the substrates prepared by adding activated carbon at low temperature. With increasing of temperature, the gases flow and diffusion speed up, and the catalytic reactions are greatly affected by TPB. The more the TPB is, the higher the methane conversion efficiency is. TPB amount is influenced by the porosity and the pore structure of the substrates. The LSCM porous anode pellets prepared by adding activated carbon have the uniform pore distribution and the moderate pore size, as well as high porosity shown in Fig.4 and Fig.3, and the pore structures are benefit for the catalytic reactions. In a word, the methane conversion efficiency of the substrate prepared by adding activated carbon is higher than that prepared by adding starch or graphite when temperature is above $675^{\circ} \mathrm{C}$.

\section{Conclusions}

1) LSCM anode substrates obtained by GNP are mainly the perovskite phases, and meet the experimental design requirements.

2) The porosities of LSCM substrates prepared by adding $20 \mathrm{wt} \%$ activated carbon, $35 \mathrm{wt} \%$ graphite and $8 \mathrm{wt} \%$ starch are $44.6 \%, 37.6 \%$ and $45 \%$, respectively. The distribution of pores of substrates prepared by adding activated carbon as the pore-former is uniform and the pore size is moderate.

3) The peaks of the methane conversion efficiency appear at $700{ }^{\circ} \mathrm{C}$. The anode substrates prepared by adding $20 \mathrm{wt} \%$ activated carbon has the highest conversion efficiency of $71.88 \%$ for methane gas, the porous LSCM substrates have good catalytic activity for methane at high temperature.

\section{References}

1 Appleby A J. Energy[J], 1996, 21(7-8): 521

2 Minh N Q. Journal of the American Ceramic Society[J], 1993, 76(3): 563

3 Meng G Y, Liu W Y, Peng D K. Ionics[J], 1998, 4(5-6): 451

4 Singhal S C. Solid State Ionics[J], 2000, 135(1-4): 305

5 Yang Z G. International Materials Reviews[J], 2008, 53(1): 39

6 Zhang L, Jiang S P, Wang W et al. Journal of Power Sources [J], 2007, 170(1): 55

7 Kuroda K, Hashimoto I, Adachi K et al. Solid State Ionics[J], 132(3-4): 199

8 Yang Y L, Lee T H, Qiu L et al. Solid State Ionics[J], 1995, 76(3-4): 369

9 Matsuzaki Y, Yasuda I. Solid State Ionics[J], 2000, 132(3-4): 261

10 Steele B C, Kelly I, Middleton H et al. Solid State Ionics[J], 1988, 28-30(2): 1547

11 Tao S W, John T S. Nature Materials[J], 2003, 2: 320

12 Chen X H, Ma W H, Yang B. Transactions of Nonferrous Metals Society of China[J], 2007, 17: 998

13 Haslam J J, Pham A Q, Chung B W et al. Journal of the Ameri- 
can Ceramic Society[J], 2005, 88(3): 513

14 Sahu A K, Ghosh A, Suri A K. Ceramics International[J], 2009, 35(6): 2493

15 Liu M Y, Yu B, Xu J M. International Journal of Hydrogen Energy[J], 2010, 35(7): 2670

16 Sanson A, Pinasco P, Roncari E. Journal of the European Ceramic Society[J], 2008, 28(6): 1221

17 Bi L, Fang S M, Tao Z T et al. Journal of the European Ceramic Society[J], 2009, 29(12): 2567

18 Clemmer R M, Corbin S F. Solid State Ionics[J], 2004, 166(3-4): 251

19 Zhao L J, Huang X Q, Zhu R B. Journal of Physics and Chemistry of Solids[J], 2009, 69(8): 2019

$20 \mathrm{Hu} \mathrm{J}$ Y, Lu Z, Chen K F et al. Journal of Membrane Science[J], 2008, 318(1-2): 445

21 Lee J H, Heo J W, Lee D S et al. Solid State Ionics[J], 2003,
158(3-4): 225

22 Liu R H, Ma W H, Wan H et al. Acta Scientiarum Naruralium Universitatis Sunyatseni[J], 2007, 46(Suppl.): 293

23 Liu R H, Du Q S, Ma W H et al. Journal of Rare Earths[J], 2006, 24(S): 98

$24 \mathrm{Yu}$ J, Chen X H, He T et al. Acta Scientiarum Naturalium Universitatis Sunyatseni $[\mathrm{J}], 2009,48(2): 164$

25 Zhou S, Xu Y B, Wang C H et al. Acta Tabacaria Sinica[J], 2011, 17(5): 1

26 Bi L, Fang S M, Tao Z T et al. Journal of the European Ceramic Society[J], 2009, 29: 2567

27 Xu S, Wang X, Zhan R. Progress in Chemistry[J], 2003, 15(2): 141

28 Patrick D F V, Malcolm L G, Anthony K et al. Catalysis Letters [J], 1990, 6(2): 181

\title{
多孔阳极支撑固体氧化物燃料电池用造孔剂的研究
}

\author{
阳建君 ${ }^{1}$, 马文会 ${ }^{1}$, 于 洁 $^{1}$, 陈秀华 ${ }^{2}$, 孙红燕 ${ }^{1}$, 谢于柄 ${ }^{1}$ \\ (1. 昆明理工大学 真空冶金国家工程实验室, 云南 昆明 650093)
}

(2. 云南大学, 云南 昆明 650091)

\begin{abstract}
摘 要: 采用甘氨酸硝酸盐法合成了超细的 $\mathrm{La}_{0.7} \mathrm{Sr}_{0.3} \mathrm{Cr}_{0.5} \mathrm{Mn}_{0.5} \mathrm{O}_{3-\delta}(\mathrm{LSCM})$ 粉末, 并把制备的阳极粉末与 3 种不同含量的造孔剂活性炭、 淀粉和石墨混合制备多孔阳极基底。应用阿基米德排水法测试了多孔阳极基底的孔隙率，得到最大孔隙率为 45\%。接着再采用 SEM、 EDS 和 XRD 等材料表征手段对阳极基底的表面形貌和结构进行了分析, 结果显示混合 20\% (质量分数) 的活性炭制备的阳极基底孔隙分 布均匀, 并没有裂纹出现。甲烷催化实验得到混合 $20 \%$ 活性炭造孔剂制备的阳极基底在高温下的催化性能最好, 甲烷转化效率达到 $71.88 \%$.

关键词: 甘氨酸硝酸盐法; 阳极基底; 孔隙率; 甲烷转化效率
\end{abstract}

作者简介: 阳建君, 男, 1985 年生, 博士生, 昆明理工大学冶金工程系, 云南 昆明 650093, 电话: 0871-5161583, E-mail: yjjsofc@yahoo.cn 